\title{
Effects of Cutting Length and Position on the Seed Yield and Quality of Tossa Jute (Corchorus olitorius L.)
}

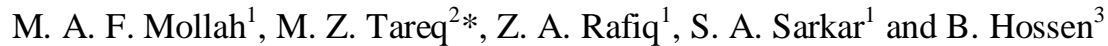 \\ ${ }^{1}$ Bangladesh Jute Research Institute, Regional Station, Rangpur, Bangladesh \\ ${ }^{2} J u t e$ Agriculture Experimental Station, BJRI, Jagir, Manikganj, Bangladesh \\ ${ }^{3}$ Dept. of Agricultural Extension, Ministry of Agriculture, Dhaka-1215, Bangladesh \\ *Corresponding author and Email: zablulbarj@gmail.com
}

Received: 23 March $2018 \quad$ Accepted: 23 June 2018

\begin{abstract}
An experiment was conducted at the research field of Jute Research Regional Station of Bangladesh Jute Research Institute (BJRI) at Kishoreganj during August 2009 to January 2010 to assess the effect of cutting length and position of cutting on seed yield and quality of tossa jute (Corchorus olitorius L.). Three cutting lengths $(15 \mathrm{~cm}, 20 \mathrm{~cm}$ and $25 \mathrm{~cm})$ and three cutting positions ( $1^{\text {st }}$ top, $2^{\text {nd }}$ top and $3^{\text {rd }}$ top) were the treatments. The experiment was laid out in a Randomized Complete Block Design (RCBD) with three replications. The highest seed yield $\left(917 \mathrm{~kg} \mathrm{ha}^{-1}\right)$ was obtained from $1^{\text {st }}$ top x $15 \mathrm{~cm}$ interaction and the lowest $\left(811 \mathrm{~kg} \mathrm{ha}^{-1}\right)$ was recorded in $3^{\text {rd }}$ top x $25 \mathrm{~cm}$ cutting length. The highest seed germination (89\%), field emergence $(87 \%)$ and accelerated ageing $(73 \%)$ were recorded from $1^{\text {st }}$ top $\mathrm{x}$ $15 \mathrm{~cm}$ interaction and the lowest seed germination $(83.00 \%)$, field emergence $(81 \%)$ and accelerated ageing (72) were recorded in $3^{\text {rd }}$ top x $25 \mathrm{~cm}$ cutting length. The upper position of cutting produced the highest yield and best quality seeds.
\end{abstract}

Keywords: Cutting length, cutting position, yield, quality, jute seed.

\section{Introduction}

Jute (Corchorus sp.) is the principal fiber crop of Bangladesh. It accounts for $6 \%$ of the foreign currency earnings from exports (Islam, 2009). Jute is predominantly grown for fiber rather than seed production. Despite so much importance of jute fibre, very little attention has been given on its research mainly on seed production practices. Moreover, the country faces an acute shortage of jute seeds every year. Bangladesh requires 40004500 MT of jute seeds annually, whereas production by Bangladesh Agricultural Development Corporation (BADC) is only 8001000 MT. The farmers produce 400-600 MT.
Rest of the demand is met up by importing mostly from India (Pulok et al., 2014). Conventionally, farmers sow jute seeds during March-April for fibre production and a part of it is kept at the corner of the land for seed production. Remnant part of fibre crop in its long stay in the field experiences natural calamities like hail storm, diseases and insect pest infestations, which results in a bad harvest in respect to both quality and quantity of seeds.

Jute is a photoperiod sensitive and short-day plant. It is evident from earlier report that jute plants induce flowers later or do not flower at all below 14 or above hours of photoperiod. It 
hastens flower, no matter whenever planted, on or subjected to short days of around 12 hours (Husain, 1977). However, if it is planted in June or later, the plants exhibit stunted growth and profuse branching and induce flowers prematurely at the juvenile stage of crop due to short photoperiodic effect.

Vegetative propagation of jute plants is an improved technique in which about $20-25 \mathrm{~cm}$ plant tops are taken off from normal fibre plants at harvested and are planted in puddled field in the months from June and July. Sohel et al. (2002) reported good survival and increased seed yield of jute through top cutting method. Besides, plant tops at harvest of fibre crop contribute nothing to fiber yield rather can be used for growing a second crop for seed production.

Yield and quality of seeds varied on the basis of position of top cutting due to growth hormone produce at the top of the plant (Pandey and Sinha, 2006). Seed production of jute crop is a great problem now a day. Farmers are not interested to grow jute seeds crop in traditional ways. Besides, modern varieties of $C$. olitorius jute produce very poor seed yields in traditional method. Though the late jute seed production technology developed by BJRI becomes promising, the sowing of late jute seed crop is usually hampered due to heavy rainfall. To avoid this situation, planting of top cuttings in the wetland during July to September may be an alternative way for quality seed production in the late season. However, information on appropriate cutting positions and lengths for seed production of jute is scarcely available. The present study was, therefore, conducted to determine the effects of cutting length and position on the seed yield and quality of jute.

\section{Materials and Methods}

A field experiment was conducted at the Jute Research Regional Station, Kishoreganj, of Bangladesh during August/2009 to January/2010 to study the effect of cutting length and position on seed yield and quality of tossa jute. The soil was sandy loam to loam in texture which belongs to the Old Brahmaputra floodplain soils (AEZ 9). The type of land was high and soil pH was 6.4. The diurnal ranges of air temperature during the experimentation periods were $23.8^{\circ} \mathrm{C}$ to $35.0^{\circ} \mathrm{C}$ and $10.4^{\circ} \mathrm{C}$ to $28.0^{\circ} \mathrm{C}$, respectively. Three types of cutting lengths e.g., $15 \mathrm{~cm}, 20 \mathrm{~cm}, 25 \mathrm{~cm}$ and three types of top cutting position e. g., top $\left(1^{\text {st }}\right.$ top), middle ( $2^{\text {nd }}$ top), bottom ( $3^{\text {rd }}$ top) position were used as plant materials in this experiment. The experiment was laid-out in a randomized complete block design (RCBD) with three replications.

The experimental plots were fertilized with urea, triple super phosphate (TSP), muriate of potash (MoP) and gypsum @ 200-50-60-95 kg ha ${ }^{-1}$, respectively. All fertilizers except urea were applied during final land preparation. Urea was top dressed in three equal splits at 15, 30 and 45 days after sowing (DAS). Weeding was done by hand at 25 and 45 days after sowing (DAS). The crop was infested by mealy bug and white fly at the vegetative stage and those were effectively controlled by spraying Ripcord 10 EC @ $2 \mathrm{mlL}^{-1}$ of water for three times at an interval of 10 days. No irrigation was applied while excess water was drained out as and when necessary. The crop was harvested at maturity (when $80 \%$ pods became brown). Plant survivalism ${ }^{-2}$, plant height, primary branches plant $^{-1}$, secondary branches plant $^{-1}$ and capsules plant ${ }^{-1}$, seeds capsule ${ }^{-1}$, capsule length, capsule diameter, seed yield, stick yield, germination, field emergence and accelerating percent were recorded. The crop was harvested on 7-8 January in 2010 (180 DAT). After harvest the crop was dried for three days and then threshed by beating with a stick. Seeds were then cleaned and dried for another five days in the sun to bring seed moisture content to below $10 \%$.

\subsection{Germination test}

Germination test was conducted following wait tissue paper method. One hundred seeds in four replications were placed on the moist tissue paper (Bashundhara kitchen towel) in petridish 
(11 $\mathrm{cm}$ diameter). The petridishes were kept in the germinator at $30 \pm 1^{\circ} \mathrm{C}$. Daily counting of the germinating seedlings were done up to 8 days of seed setting. The number of normal seedlings was counted at 8 DAS and the germination percentage of seed was measured as:

Germination $(\%)=$

Number of normal seedling

Number of seed sown

\subsection{Accelerated ageing (AA) test}

Accelerated ageing seed was done by taking $15 \mathrm{~g}$ seeds in accelerated ageing chamber and exposing the seeds to $41^{\circ} \mathrm{C}$ temperature and $100 \%$ RH for 72 hours. For conducting the AA test, seeds were weighed and placed on a screen tray $(10.0 \times 3.5 \times 3.0 \mathrm{~cm})$ which was inserted into an inner chamber (plastic box: $10.0 \times 6.0 \times 4.0$ $\mathrm{cm}$ ) containing $50 \mathrm{ml}$ of water. The boxes were covered with lids and kept airtight. The inner chamber was placed into an accelerated ageing (outer) chamber. During the ageing period the seeds absorb moisture from the humid environment within the inner chamber and were stressed by high temperature and RH. After accelerated ageing, germination test of seeds was done using modified paper folding method (ISTA, 1999).

\subsection{Field emergence (FE)}

Field emergence was calculated according to Mollah (2014) using the following formula:

Field emergence $(\%)=$

Number of normal seedling

------------------------------- $\times 100$

Number of seed sown

\subsection{Statistical analysis}

Data were analyzed by using the Analysis of Variance Technique and differences among the treatment means were adjudged by Duncan's Multiple Range Test (DMRT) (Gomez and Gomez, 1984) following a statistical computer package (MSTATC).

\section{Results and Discussion}

\subsection{Cutting length on survivalist}

Cutting length had significant effect on plant survivalist of jute seed production (Table 1). The highest plant survivalist (14.5) was recorded in $25 \mathrm{~cm}$ cutting length. It may be due to more node contain in this cutting. The lowest plant survivalist (12.7) was recorded in $20 \mathrm{~cm}$ cutting length. Cutting position also has significant effect on plant survivalist of jute seed production (Table 2). The highest plant survivalist (14.4) was recorded in $2^{\text {nd }}$ top it may be due to more auxin produce in the upper part of cutting and $1^{\text {st }}$ top may be vulnerable (Pandey and Sinha, 2006). The lowest plant population (12.8) was recorded in $3^{\text {rd }}$ top. From cutting length and position interaction effect it was evident that on the highest plant population (15.4) was found in $3^{\text {rd }}$ top x $25 \mathrm{~cm}$ followed by $2^{\text {nd }}$ top x $20 \mathrm{~cm}$ (15.3). The lowest plant population (10.0) was found in $3^{\text {rd }}$ top x $20 \mathrm{~cm}$ interaction (Table 5). Similar result was reported by BJRI (2005-06) and Zigene and Kassahun (2016).

\subsection{Cutting length on plant height}

Plant height is an important yield contributing character. Cutting length and position had significant effect on plant height. The highest plant height $(1.33 \mathrm{~m})$ was recorded at $25 \mathrm{~cm}$ cutting length and the lowest one $(1.26 \mathrm{~m})$ was in $20 \mathrm{~cm}$ cutting length followed by $1.29 \mathrm{~m}$ at 15 $\mathrm{cm}$ cutting length (Table 1$)$. The highest plant height $(1.35 \mathrm{~m})$ was recorded in $1^{\text {st }}$ top and the lowest plant height $(1.26 \mathrm{~m})$ was recorded in $2^{\text {nd }}$ and $3{ }^{\text {rd }}$ top (Table 2). Interaction effect of cutting length and position shows that the highest plant height $(1.38 \mathrm{~m})$ was found in $1^{\text {st }}$ top $\times 15 \mathrm{~cm}$ followed by $1^{\text {st }}$ top x $25 \mathrm{~cm}$. The lowest plant height $(1.19 \mathrm{~m})$ was found in $3^{\text {rd }}$ top $\times 20 \mathrm{~cm}$ interaction (Table 5). Similar result was reported by BJRI (2005-06) and Zigene and Kassahun (2016).

\subsection{Primary branch per plant}

Primary branch in a jute plant is an important seed yield contributing character. Cutting length and position had significant effect on primary 
branch per plant. The highest number of primary branch per plant (1.90) was recorded at $25 \mathrm{~cm}$ cutting followed by (1.80) in $20 \mathrm{~cm}$ cutting and the lowest one (1.60) was at $15 \mathrm{~cm}$ cutting (Table 1). Similarly the number of primary branch was the highest (1.93) in $3^{\text {rd }}$ top, followed by $(1.83)$ in $2^{\text {nd }}$ top and the lowest one (1.53) was recorded in $1^{\text {st }}$ top (Table 2). Interaction of cutting length and cutting position shows that the highest number of primary branch (2.3) was found in $3^{\text {rd }}$ top x $25 \mathrm{~cm}$ cutting and the lowest (1.5) was found in $1^{\text {st }}$ top $\times 15 \mathrm{~cm}, 1^{\text {st }}$ top $\times 25$ $\mathrm{cm}$ and $3^{\text {rd }}$ top x $15 \mathrm{~cm}$ cutting (Table 5). Similar result was reported by Zigene and Kassahun (2016).

\subsection{Secondary branch per plant}

Number of secondary branch per plant was varied with cutting length and position.. The number of secondary branch per plant was the highest (3.47) in $20 \mathrm{~cm}$ cutting, followed by $3.38 \mathrm{~cm}$ in $15 \mathrm{~cm}$ cutting and the lowest one (3.25) was in $25 \mathrm{~cm}$ cutting (Table 1). The highest secondary branch (3.80) was recorded in $2^{\text {nd }}$ top and the lowest secondary branch (3.06) was recorded in $1^{\text {st }}$ top followed by 3.23 in $3^{\text {rd }}$ top (Table 2). From cutting length and position interaction effect on the highest secondary branch (4.1) was found in $2^{\text {nd }}$ top x $20 \mathrm{~cm}$ and the lowest secondary branch (2.8) was found in $1^{\text {st }}$ top x $25 \mathrm{~cm}$ (Table 5).

\subsection{Number of capsule per plant}

Number of capsule per plant is an important seed yield contributing character in jute. Cutting length and position had significant effect on capsule number per plant. The highest number of capsule per plant (38) was recorded in $25 \mathrm{~cm}$ cutting and the lowest one (33) was in $20 \mathrm{~cm}$ cutting length (Table 1). For cutting position the highest number of capsule per plant (37) was recorded in $1^{\text {st }}$ top and the lowest one (35) was recorded in $2^{\text {nd }}$ top (Table 2 ). Interaction effect of cutting length and position revealed that the highest capsule per plant (41) in $1^{\text {st }}$ top x $25 \mathrm{~cm}$, followed by $2^{\text {nd }} \times 25 \mathrm{~cm}$ and the lowest one (33) was obtained in $3^{\text {rd }}$ top x $15 \mathrm{~cm}$ (Table 5).

\subsection{Capsule length and diameter}

Capsule length and diameter are important seed yield contributing characters of jute. Cutting length and position had significant effect on capsule length and diameter. The highest capsule length $(6.27 \mathrm{~cm})$ and diameter $(5.33 \mathrm{~mm})$ was recorded in $15 \mathrm{~cm}$ cutting and the lowest capsule length $(6.03 \mathrm{~cm})$ and diameter $(5.19 \mathrm{~mm})$ was in $20 \mathrm{~cm}$ cutting (Table 1). The highest capsule length $(6.20 \mathrm{~cm})$ and diameter $(5.32 \mathrm{~mm})$ was recorded in $2^{\text {nd }}$ top and the lowest capsule length $(6.03 \mathrm{~cm})$ and diameter $(5.19 \mathrm{~mm})$ was recorded in $3^{\text {rd }}$ top (Table 2). Interaction of cutting length and position he shows the highest capsule length $(6.33 \mathrm{~cm})$ and diameter $(5.39 \mathrm{~mm})$ in $2^{\text {nd }}$ top $x$ $20 \mathrm{~cm}$ and the lowest capsule length $(5.64 \mathrm{~cm})$ and diameter $(5.09 \mathrm{~mm})$ was found in $3^{\text {rd }}$ top $\mathrm{x}$ $20 \mathrm{~cm}$ (Table 5).

\subsection{Number of seed per capsule}

The highest number of seed per capsule (153) was recorded in $15 \mathrm{~cm}$ cutting and the lowest seed per capsule (145) was in $20 \mathrm{~cm}$ cutting length (Table 1). The highest number of seed per capsule (154) was recorded in $2^{\text {nd }}$ top and the lowest number of seed per capsule (145) was recorded in $3^{\text {rd }}$ top (Table 2 ). From cutting length and position interaction effect on the highest number of seed per capsule (156) was found in $2^{\text {nd }}$ top $\times 20 \mathrm{~cm}$ followed by 155 in $3^{\text {rd }} \times 15 \mathrm{~cm}$, 154 in $2^{\text {nd }} \times 15 \mathrm{~cm}$ and the lowest number of seed per capsule (137) was found in $3^{\text {rd }}$ top x 20 $\mathrm{cm}$ (Table 5). Similar result was reported by BJRI (2005-06).

\subsection{Seed and stick yield}

Seed and stick yields are the ultimate goal of jute seed production. Cutting length and position has significant effect on seed yield and stick yield. The highest seed yield (798 kg/ha) and stick yield ( $3387 \mathrm{~kg} / \mathrm{ha}$ ) was recorded in $25 \mathrm{~cm}$ cutting length and the lowest seed yield (744 kg/ha) and stick yield $(2848 \mathrm{~kg} / \mathrm{ha})$ was in $20 \mathrm{~cm}$ cutting length (Table 1). The highest seed yield ( 827 $\mathrm{kg} / \mathrm{ha}$ ) and stick yield (3338 kg/ha) was recorded in $1^{\text {st }}$ top and the lowest seed yield $(727 \mathrm{~kg} / \mathrm{ha})$ and stick yield $(2901 \mathrm{~kg} / \mathrm{ha})$ was recorded in $3^{\text {rd }}$ top (Table 2). 
Table 1. Effect of cutting length on the seed yield and yield attributes of jute

\begin{tabular}{|c|c|c|c|c|c|c|c|c|c|c|}
\hline $\begin{array}{l}\text { Length of } \\
\text { cutting }(\mathrm{cm})\end{array}$ & $\begin{array}{c}\text { Plant } \\
\text { survivalist } \\
/ \mathrm{m}^{2} \text { (no.) }\end{array}$ & $\begin{array}{l}\text { Plant } \\
\text { height } \\
\text { (m) }\end{array}$ & $\begin{array}{c}\text { Primary } \\
\text { branches } \\
\text { /plant (no.) }\end{array}$ & $\begin{array}{l}\text { Secondary } \\
\text { branches } \\
\text { /plant (no.) }\end{array}$ & $\begin{array}{c}\text { Capsule } \\
\text { s/ Plant } \\
\text { (no.) }\end{array}$ & $\begin{array}{c}\text { Length } \\
\text { of capsule } \\
(\mathrm{cm})\end{array}$ & $\begin{array}{l}\text { Dia. Of } \\
\text { capsule } \\
(\mathrm{mm})\end{array}$ & $\begin{array}{c}\text { Seed/ } \\
\text { capsule } \\
\text { (no.) }\end{array}$ & $\begin{array}{c}\text { Seed } \\
\text { yield } \\
(\mathrm{kg} / \mathrm{ha})\end{array}$ & $\begin{array}{c}\text { Stick } \\
\text { yield } \\
(\mathrm{kg} / \mathrm{ha})\end{array}$ \\
\hline 15 & $13.3 \mathrm{~b}$ & $1.29 \mathrm{~b}$ & $1.60 \mathrm{c}$ & $3.38 \mathrm{~b}$ & $36 b$ & $6.27 \mathrm{a}$ & $5.33 \mathrm{a}$ & $153 \mathrm{a}$ & $785 \mathrm{~b}$ & $2918 b$ \\
\hline 20 & $12.7 \mathrm{c}$ & $1.26 \mathrm{~b}$ & $1.80 \mathrm{~b}$ & $3.47 \mathrm{a}$ & $33 c$ & $6.03 c$ & $5.19 b$ & $145 c$ & $744 c$ & $2848 \mathrm{c}$ \\
\hline 25 & $14.5 \mathrm{a}$ & $1.33 \mathrm{a}$ & $1.90 \mathrm{a}$ & $3.25 \mathrm{c}$ & $38 \mathrm{a}$ & $6.10 \mathrm{~b}$ & $5.20 \mathrm{~b}$ & $147 b$ & $798 \mathrm{a}$ & $3387 \mathrm{a}$ \\
\hline $\operatorname{LSD}(5 \%)$ & 0.16 & 0.03 & 0.03 & 0.03 & 0.06 & 0.03 & 0.03 & 1.17 & 0.49 & 3.49 \\
\hline $\mathrm{CV}(\%)$ & 1.21 & 1.58 & 1.29 & 0.80 & 0.19 & 0.50 & 0.48 & 0.79 & 0.06 & 0.11 \\
\hline
\end{tabular}

Table 2. Effect of cutting position on the seed yield and yield attributes of jute

\begin{tabular}{|c|c|c|c|c|c|c|c|c|c|c|}
\hline $\begin{array}{l}\text { Position } \\
\text { of cutting }\end{array}$ & $\begin{array}{c}\text { Plant } \\
\text { survivalist/ } \\
\mathrm{m}^{2} \text { (no.) }\end{array}$ & $\begin{array}{c}\text { Plant } \\
\text { height } \\
\text { (m) }\end{array}$ & $\begin{array}{c}\text { Primary } \\
\text { branches } \\
\text { /plant } \\
\text { (no.) }\end{array}$ & $\begin{array}{c}\text { Secondary } \\
\text { branches } \\
\text { /plant } \\
\text { (no.) }\end{array}$ & $\begin{array}{c}\text { Capsule } \\
\text { s/ Plant } \\
\text { (no.) }\end{array}$ & $\begin{array}{l}\text { Length } \\
\text { of capsule } \\
(\mathrm{cm})\end{array}$ & $\begin{array}{c}\text { Dia. Of } \\
\text { capsule } \\
(\mathrm{mm})\end{array}$ & $\begin{array}{c}\text { Seed/ } \\
\text { capsule } \\
\text { (no.) }\end{array}$ & $\begin{array}{c}\text { Seed } \\
\text { yield } \\
(\mathrm{kg} / \mathrm{ha})\end{array}$ & $\begin{array}{c}\text { Stick } \\
\text { yield } \\
(\mathrm{kg} / \mathrm{ha})\end{array}$ \\
\hline $1^{\text {st }}$ top & $13.3 b$ & $1.35 \mathrm{a}$ & $1.53 c$ & $3.06 \mathrm{c}$ & $37 \mathrm{a}$ & $6.18 \mathrm{a}$ & $5.22 b$ & $147 b$ & $827 a$ & $3338 a$ \\
\hline $2^{\text {nd }}$ top & $14.4 \mathrm{a}$ & $1.26 \mathrm{~b}$ & $1.83 b$ & $3.80 \mathrm{a}$ & $35 b$ & $6.20 \mathrm{a}$ & $5.32 \mathrm{a}$ & $154 \mathrm{a}$ & $772 b$ & $2912 b$ \\
\hline $3^{\text {rd }}$ top & $12.8 \mathrm{c}$ & $1.26 \mathrm{~b}$ & $1.93 \mathrm{a}$ & $3.23 b$ & $35 \mathrm{~b}$ & $6.03 \mathrm{~b}$ & $5.19 b$ & $145 c$ & $727 \mathrm{c}$ & 2901c \\
\hline $\operatorname{LSD}(5 \%)$ & 0.16 & 0.03 & 0.03 & 0.03 & 0.06 & 0.03 & 0.03 & 1.17 & 0.49 & 3.49 \\
\hline $\mathrm{CV}(\%)$ & 1.21 & 1.58 & 1.29 & 0.80 & 0.19 & 0.50 & 0.48 & 0.79 & 0.06 & 0.11 \\
\hline
\end{tabular}

Table 3. Effect of cutting length on the seed quality of jute

\begin{tabular}{lccc}
\hline Length of cutting $(\mathrm{cm})$ & Germination $(\%)$ & Accelerated Ageing $(\%)$ & Field Emergence $(\%)$ \\
\hline 15 & $86.00 \mathrm{a}$ & $72.00 \mathrm{a}$ & $84.00 \mathrm{a}$ \\
20 & $86.00 \mathrm{a}$ & $71.33 \mathrm{a}$ & $84.00 \mathrm{a}$ \\
25 & $85.00 \mathrm{a}$ & $72.00 \mathrm{a}$ & $83.00 \mathrm{a}$ \\
\hline LSD $(5 \%)$ & 2.23 & 1.67 & 1.66 \\
CV $(\%)$ & 3.10 & 2.77 & 2.36 \\
\hline
\end{tabular}


Table 4. Effect of cutting position on the seed quality attributes of jute

\begin{tabular}{|c|c|c|c|}
\hline Position of cutting & Germination (\%) & A. Ageing (\%) & Field Emergence $(\%)$ \\
\hline $1^{\mathrm{st}}$ top & $87.67 \mathrm{a}$ & $72.00 \mathrm{a}$ & $85.67 \mathrm{a}$ \\
\hline $2^{\text {nd }}$ top & $85.33 \mathrm{~b}$ & $72.33 \mathrm{a}$ & $83.33 \mathrm{ab}$ \\
\hline $3^{\text {rd }}$ top & $84.00 \mathrm{~b}$ & $71.00 \mathrm{a}$ & $82.00 \mathrm{~b}$ \\
\hline $\operatorname{LSD}(5 \%)$ & 2.23 & 1.67 & 1.66 \\
\hline $\mathrm{CV}(\%)$ & 3.10 & 2.77 & 2.36 \\
\hline
\end{tabular}

Table 5. Interaction effect of cutting position and length on the seed yield and yield attributes of jute

\begin{tabular}{|c|c|c|c|c|c|c|c|c|c|c|}
\hline Treatment & $\begin{array}{c}\text { Plant } \\
\text { survivalist } \\
/ \mathrm{m}^{2} \text { (no.) }\end{array}$ & $\begin{array}{l}\text { Plant } \\
\text { height } \\
(\mathrm{m})\end{array}$ & $\begin{array}{c}\text { Primary } \\
\text { branches } \\
\text { /plant (no.) }\end{array}$ & $\begin{array}{l}\text { Secondary } \\
\text { branches } \\
\text { /plant (no.) }\end{array}$ & $\begin{array}{c}\text { Capsules } \\
\text { / Plant } \\
\text { (no.) }\end{array}$ & $\begin{array}{c}\text { Length } \\
\text { of capsule } \\
(\mathrm{cm})\end{array}$ & $\begin{array}{l}\text { Dia. of } \\
\text { capsule } \\
(\mathrm{mm})\end{array}$ & $\begin{array}{c}\text { Seed/ } \\
\text { capsule } \\
\text { (no.) }\end{array}$ & $\begin{array}{c}\text { Seed } \\
\text { yield } \\
(\mathrm{kg} / \mathrm{ha})\end{array}$ & $\begin{array}{c}\begin{array}{c}\text { Stick } \\
\text { yield } \\
(\mathrm{kg} / \mathrm{ha})\end{array} \\
\end{array}$ \\
\hline $1^{\text {st }}$ topx 15 & $13.9 \mathrm{c}$ & $1.38 \mathrm{a}$ & $1.5 \mathrm{f}$ & $3.3 \mathrm{e}$ & $37 d$ & $6.21 \mathrm{~b}$ & $5.40 \mathrm{a}$ & $151 \mathrm{~b}$ & $917 \mathrm{a}$ & $3638 b$ \\
\hline $1^{\text {st }}$ topx 20 & $12.8 \mathrm{e}$ & $1.30 \mathrm{bc}$ & $1.6 \mathrm{e}$ & $3.1 \mathrm{~g}$ & $33 g$ & $6.13 c$ & $5.09 \mathrm{~d}$ & $142 d$ & $805 d$ & $3194 c$ \\
\hline $1^{\text {st }}$ topx 25 & $13.2 \mathrm{~d}$ & $1.37 \mathrm{a}$ & $1.5 \mathrm{f}$ & $2.8 \mathrm{~h}$ & $41 \mathrm{a}$ & $6.19 b$ & $5.16 c$ & $147 \mathrm{c}$ & $761 \mathrm{e}$ & $3183 d$ \\
\hline $2^{\text {nd }}$ topx 15 & 13.0de & $1.23 \mathrm{de}$ & $1.8 \mathrm{~d}$ & $3.7 \mathrm{~b}$ & $38 \mathrm{c}$ & $6.31 \mathrm{a}$ & $5.31 b$ & $154 \mathrm{a}$ & $733 \mathrm{f}$ & $2655 f$ \\
\hline $2^{\text {nd }}$ topx 20 & $15.3 \mathrm{a}$ & $1.28 \mathrm{bcd}$ & $1.8 \mathrm{~d}$ & $4.1 \mathrm{a}$ & $34 \mathrm{e}$ & $6.33 \mathrm{a}$ & $5.39 \mathrm{a}$ & $156 a$ & $761 \mathrm{e}$ & $2905 \mathrm{e}$ \\
\hline $2^{\text {nd }}$ topx 25 & $14.9 \mathrm{~b}$ & $1.28 \mathrm{bcd}$ & $1.9 \mathrm{c}$ & $3.6 \mathrm{c}$ & $33 f$ & $5.95 \mathrm{~d}$ & $5.27 \mathrm{~b}$ & $151 \mathrm{~b}$ & $822 b$ & $3177 d$ \\
\hline $3^{\text {nd }}$ topx 15 & $12.9 \mathrm{e}$ & $1.25 \mathrm{~cd}$ & $1.5 \mathrm{f}$ & $3.1 \mathrm{~g}$ & $33 \mathrm{f}$ & $6.28 \mathrm{a}$ & $5.29 b$ & $155 \mathrm{a}$ & $705 \mathrm{~g}$ & $2461 \mathrm{~g}$ \\
\hline $3^{\text {nd }}$ topx 20 & $10.0 \mathrm{f}$ & $1.19 \mathrm{e}$ & $2.0 \mathrm{~b}$ & $3.2 \mathrm{f}$ & $33 f$ & $5.64 \mathrm{e}$ & $5.09 \mathrm{~d}$ & $137 \mathrm{e}$ & $666 \mathrm{~h}$ & $2444 h$ \\
\hline $3^{\text {nd }}$ topx 25 & $15.4 \mathrm{a}$ & $1.33 \mathrm{ab}$ & $2.3 \mathrm{a}$ & $3.4 \mathrm{~d}$ & $40.6 \mathrm{~b}$ & $6.17 \mathrm{bc}$ & $5.18 \mathrm{c}$ & $142 d$ & $811 \mathrm{c}$ & $3800 \mathrm{a}$ \\
\hline LSD $(5 \%)$ & 0.28 & 0.05 & 0.05 & 0.05 & 0.11 & 0.05 & 0.05 & 2.03 & 0.86 & 6.05 \\
\hline $\mathrm{CV}(\%)$ & 1.21 & 1.58 & 1.29 & 0.80 & 0.19 & 0.50 & 0.48 & 0.79 & 0.06 & 0.11 \\
\hline
\end{tabular}


Table 6. Interaction effect of cutting position and length on the seed quality of jute

\begin{tabular}{lccc}
\hline Treatment & Germination (\%) & Accelerated Ageing (\%) & Field Emergence (\%) \\
\hline $1^{\text {st }}$ top x 15 & & & $87 \mathrm{a}$ \\
$2^{\text {nd }}$ top x 15 & $89 \mathrm{a}$ & $73 \mathrm{a}$ & $84 \mathrm{abcd}$ \\
$3^{\text {nd }}$ top x 15 & $86 \mathrm{abc}$ & $72 \mathrm{a}$ & $86 \mathrm{ab}$ \\
$1^{\text {st }}$ top x 20 & $88 \mathrm{ab}$ & $71 \mathrm{a}$ & $83 \mathrm{bcd}$ \\
$2^{\text {nd }}$ top x 20 & $85 \mathrm{abc}$ & $72 \mathrm{a}$ & $85 \mathrm{abc}$ \\
$3^{\text {nd }}$ top x 20 & $87 \mathrm{abc}$ & $72 \mathrm{a}$ & $82 \mathrm{~cd}$ \\
$1^{\text {st }}$ top x 25 & $84 \mathrm{bc}$ & $73 \mathrm{a}$ & $82 \mathrm{~cd}$ \\
$2^{\text {nd }}$ top x 25 & $84 \mathrm{bc}$ & $71 \mathrm{a}$ & $83 \mathrm{bcd}$ \\
$3^{\text {nd }}$ top x 25 & $85 \mathrm{abc}$ & $70 \mathrm{a}$ & $81 \mathrm{~d}$ \\
\hline LSD $(5 \%)$ & $83 \mathrm{c}$ & $72 \mathrm{a}$ & 2.88 \\
CV $(\%)$ & 3.87 & 2.89 & 2.36 \\
\hline
\end{tabular}

From cutting length and position interaction effect on the highest seed yield $(917 \mathrm{~kg} / \mathrm{ha})$ was found in $1^{\text {st }}$ top x $15 \mathrm{~cm}$ and stick yield $(3800$ $\mathrm{kg} / \mathrm{ha}$ ) was found in $3^{\text {rd }}$ top $\mathrm{x} 25 \mathrm{~cm}$ and the lowest seed yield $(666 \mathrm{~kg} / \mathrm{ha})$ and stick yield $\left(2444 \mathrm{~kg} / \mathrm{ha}\right.$ ) was found in $3^{\text {rd }}$ top x $20 \mathrm{~cm}$ (Table 5). Similar result was reported by BJRI (200506).

\subsection{Germination}

Germination percent, the most important quality parameter of jute seed was not affected significantly by cutting length but affected significantly by cutting position. The highest seed germination (87.67) was recorded in $1^{\text {st }}$ top position, followed by 85.33 in $2^{\text {nd }}$ top position and the lowest one was (84.00) recorded in $3^{\text {rd }}$ top (Table 4). Interaction effect of cutting length and position shows that the highest germination percent was $89.00 \%$ in $1^{\text {st }}$ top x $15 \mathrm{~cm}$ and the lowest one was $83.00 \%$ in $3^{\text {rd }}$ top x $25 \mathrm{~cm}$.

\subsection{Ageing}

Seed ageing percent was not affected significantly by cutting length, cutting position and cutting length $\mathrm{x}$ cutting position interaction but affected significantly by cutting position (Table 3, 4, 6).

\subsection{Field emergence}

Field emergence percent was not influenced significantly by cutting length but affected significantly by cutting position. The highest field emergence (85.67) was recorded in $1^{\text {st }}$ top position. The lowest germination (82.00) was recorded in $3^{\text {rd }}$ top position (Table 4). Germination affected significantly on cutting length $\mathrm{x}$ position interaction. The highest field emergence percent $(87.00)$ was recorded in $1^{\text {st }}$ top x $15 \mathrm{~cm}$ interaction and the lowest (81.00) was recorded in $3^{\text {rd }}$ top $\times 25 \mathrm{~cm}$ interaction (Table 6).

\section{Conclusions}

The highest yield and quality seeds were obtained from $1^{\text {st }}$ top x $15 \mathrm{~cm}$ interaction and the lowest seed yield and quality was found from $3^{\text {rd }}$ $\mathrm{x} 20 \mathrm{~cm}$ interaction. The upper position of cutting produced the highest yield and best quality seeds. It may be concluded that decreasing cutting position is the cause of reduced yield and quality of jute seed.

\section{References}

BJRI, 2005-06. Bangladesh Jute Research Institute. Annual Report, 144-145 pp.

Gomez KA., Gomez AA. 1984. Statistical procedures for Agricultural Research $2^{\text {nd }}$ Edn. John Willy and Sons., New York. 97-111pp. 
Husain M. 1977. Studies on the effect of short day length of flower induction of some selected cultivars of jute. Bangladesh Journal of Jute Fibre Research, 2 (1): 7377.

Islam MM. 2009. In: Jute seed technology. $1^{\text {st }}$ edition. Pub. By Md. Mahmudul Islam, 397, Middle Monipur, Mirpur, Dhaka1216. College Gate Book Binding and Printing, Mohammadpur, Dhaka. 160 p.

ISTA. 1999. International Rules for Seed Testing, 2003. Zurich, Switzerland, ISTA.126-131 pp.

Mollah MAF. 2014. Yield and quality of kenaf seed as influenced by production and storage environment. PhD dissertation, Department of Seed Science and Technology. Bangladesh Agricultural University, Mymensingh. 56-60 pp.
Pandey SN., Sinha BK. 2006. Plant Physiology, $4^{\text {th }}$ edition, Vikas Publishing House Pvt. Ltd., New Delhi, 447 p.

Pulok MAI., Hossain MM., Mazed HEMK., Mahabub ST., Sharmin S. 2014. Effect of storage containers on the seed quality attributes of deshi jute (Corchorus capsularis L.) International Journal of Business, Social \& Scientific Research, 2(2): 100-103.

Sohel MA., Salim M., Hossain MA. 2002. Top cutting an improved technique in jute seed production. Bangladesh Journal of Seed Science \& Technology. 6 (1\&2): 103-107.

Zigene ZD., Kassahun BM. 2016. Effect of cutting size and position on propagation ability of Sage (Salvia officinalis L.). International journal of Advanced Biological and Biomedical Research 4(1): 68-76. 